\title{
Thermoluminescence age determination for chemically selected samples of White Pumice tephra (WP) in the Kamikita plain, northeast Japan
}

\author{
Theeraporn Chuenpee*1, a, Tabito Matsu'ura*2, Osamu Nishikawa*3, \\ Takashi Uchida* ${ }^{3}$ and Isao Takashima*4
}

\begin{abstract}
Using thermoluminescence (TL) technique (multiple aliquot regeneration method), we dated White Pumice tephra (WP), an unconsolidated tephra on Middle Pleistocene (MIS 7) marine terrace deposits at the Kamikita plain, Aomori Prefecture. We collected 6 and 10 samples from WP on outcrops at Kacchi and Shichihyaku, respectively for evaluation of chemical leaching. Concentration of radiometric elements $\left(\mathrm{U}\right.$, Th and $\left.\mathrm{K}_{2} \mathrm{O}\right)$ was measured for all 16 samples. Among them, five samples were selected for TL age determination. The TL ages of three samples $(187 \pm 29 \mathrm{ka}, 230 \pm 23 \mathrm{ka}$ and $229 \pm 38 \mathrm{ka}$, weighted mean : $216 \pm 15 \mathrm{ka}$ ) well coincide with a reported age of WP (MIS 7b ; 205-210 ka), correlated with $\delta^{18} \mathrm{O}$ stratigraphy of deep-sea sediments. The TL ages of other two samples $(165 \pm 28 \mathrm{ka}$ and $265 \pm 33 \mathrm{ka})$ are beyond the error range to $205-210 \mathrm{ka}$ at mid MIS 7 . The chemistry of former three samples falls in the concentrated zone of $\mathrm{U}-\mathrm{K}_{2} \mathrm{O}$ and $T h-\mathrm{K}_{2} \mathrm{O}$ diagram. Other two samples were plotted far from concentrated zone of the same diagram. For TL age determination of unconsolidated tephra, annual dose evaluation through simple screening of chemical character is critical to obtain reasonable results.
\end{abstract}

Keywords : White Pumice tephra (WP), TL dating, unconsolidated tephra, chemical leaching, Kamikita plain, northeast Japan

\section{Introduction}

Tephras are widely found and becomes important key bed in Japan. A catalog of tephras was published to describe characteristics, method for identification and some age data (Machida and Arai, 2003). Tephra ages have been well determined using ${ }^{14} \mathrm{C}$ dating technique, varve in lacustrine sediments and oxygen isotope record in marine sediments. However, former one has older age limits around $50 \mathrm{ka}$ and later two can be applied to only lake or submarine sediments which preserve primary tephras.

Thermoluminescence (TL) technique is recognized as one of the well-suited dating methodology (Ichikawa et al., 1982 ; Nagatomo et al., 2005 ; Shitaoka et al., 2013). Using tephra quartz, TL dating technique covers the time range from a few hundred to one million years, beyond the limit of ${ }^{14} \mathrm{C}$ dating method. Basically, laboratory TL measurement is relatively easy to obtain precise equivalent dose (ED) by use of advanced machine and newly developed experimental protocols (Hashimoto et al., 2002 ; Tsukamoto and Iwata, 2005 ; Ganzawa and Maeda, 2009 ; Ogawa et al., 2011). However, tephra accompanies considerable uncertainty in annual dose (AD) estimation because unconsolidated tephra has

Received September 5, 2016. Accepted February 6, 2017.

*1 Graduate School of Engineering and Resource Sciences, Akita University. 1-1 Tegatagakuen-machi, Akita, 010-8502, Japan.

*2 Minato-ku, Tokyo, Japan.

*3 Faculty of International Resource Sciences, Akita University. 1-1 Tegatagakuen-machi, Akita, 010-8502, Japan.

*4 Professor Emeritus, Akita University. Tegatahebino, Akita, 010-0851, Japan.

*a Corresponding author : chuenpee_t@yahoo.com 
possibly undergone chemical leaching and water content change during long geologic time.

Unconsolidated tephras within eolian loess are very important age indicator for Middle-Late Pleistocene terrace chronology (e.g. Machida and Arai, 2003), therefore it is critical to find the way to reduce error factors from $\mathrm{AD}$ calculation.

White Pumice tephra (WP), which derived from an eruption of Kita-Hakkoda volcanic groups (Kudo et al., 2004) is widely distributed in the Kamikita plain, Aomori Prefecture (Fig. 1). WP has been used to establish Middle Pleistocene marine terrace chronology (Miyauchi, 1985, 1987 ; Koike and Machida, 2001 ; Matsu'ura et al., 2014) and its reported ages scatter in a wide range, $280 \pm 50 \mathrm{ka}$ (Kuwabara, 2007) and $230 \pm 50$ ka (Kudo and Kobayashi, 2013) by fission-track method, and 160-200 ka (Miyachi, 1985) and 270 ka (Kudo et al., 2004) by stratigraphical evidences. Recently, WP has been estimated to correspond to mid marine isotopic stage (MIS) 7 (around $220 \mathrm{ka}$ ) by correlation with $\delta^{18} \mathrm{O}$ stratigraphy in deep-sea sediments (Chikyu C9001C cores) off Shimokita Peninsula (Matsu'ura et al., 2014). The newest revised age is 205-210 ka (Matsu'ura et al., in press). Therefore well dated WP is a good example to test TL dating (especially AD estimation) applied to unconsolidated fall tephra of Middle Pleistocene age.

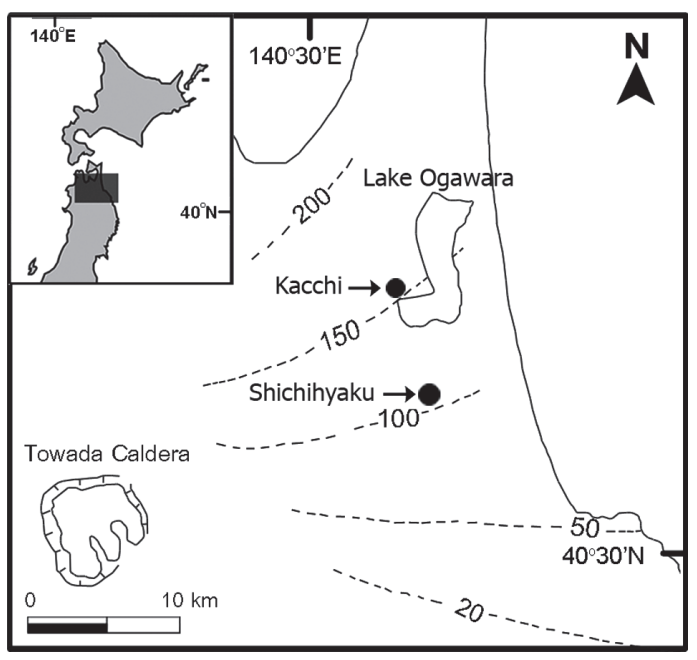

Fig. 1 Map showing survey locations WP isopachs (in cm) are quoted from Miyauchi (1987).
In this paper, we try to find the suitable way in TL age determination of the age-known unconsolidated tephra (WP) concerning about the chemical leaching and change in water content since deposition. For this purpose, we collected a large number of samples from same outcrop and then conducted chemical analyses for sample selection.

\section{Occurrence of White Pumice tephra on outcrop and samples}

Stratigraphic columns of two sampling sites were shown in Fig. 2. At Kacchi outcrop (location 4 of Matsu'ura et al., 2014), non-aerial terrace deposits (cross-bedding sand) are overlain by loess which contain WP, Orange Pumice (OrP), Toya, and Towada-Castera ( $\left.\mathrm{To}^{-} \mathrm{CP}\right)$ in ascending order. The WP is about $1 \mathrm{~m}$ thickness of argillized white color very fine tuff. It is difficult to indentify pumice and other minerals by field observation because all fractions pass to 0.25 $\mathrm{mm}$ sieve. Mineral compositions of this tephra was reported as abundant orthopyroxene with minor amphibole by microscopic observation (Matsu'ura et al., 2014). At Shichihyaku outcrop (location 5 of Matsu'ura et al., 2014), non-aerial terrace deposits (cross-bedding sand including undifferentiated pumice at the uppermost part) are overlain by loess which contains WP.

Six samples of WP were collected from Kacchi outcrop (Fig. 3). All samples were collected from fresh-looking homogeneous parts of the WP tephra layer. Sample KAC-1 is collected for full TL measurement (equivalent dose and annual dose determinations) from middle parts of the WP layer and other five samples were collected only for chemical analyses (KChem-1, 2, 3,4 and 5) with different depth $(0 \mathrm{~cm}, 10 \mathrm{~cm}$, $20 \mathrm{~cm}, 30 \mathrm{~cm}$ and $50 \mathrm{~cm}$ ) from vertical outcrop surface by using iron pipe with $5 \mathrm{~cm}$ diameter. At Shichihyaku outcrop (Fig. 3B-D), we collected four samples for full TL measurements (SCH-1A, SCH-1B, SCH-3A and SCH-3B). Samples SChem-1, 2, 3 and 4 were near-surface sediments and samples SChem-5 and 6 were from horizontal distances of $10 \mathrm{~cm}$ and $30 \mathrm{~cm}$ from the sample SChem-1, respectively. Samples SChem-1-6 were used only for chemical analyses. 

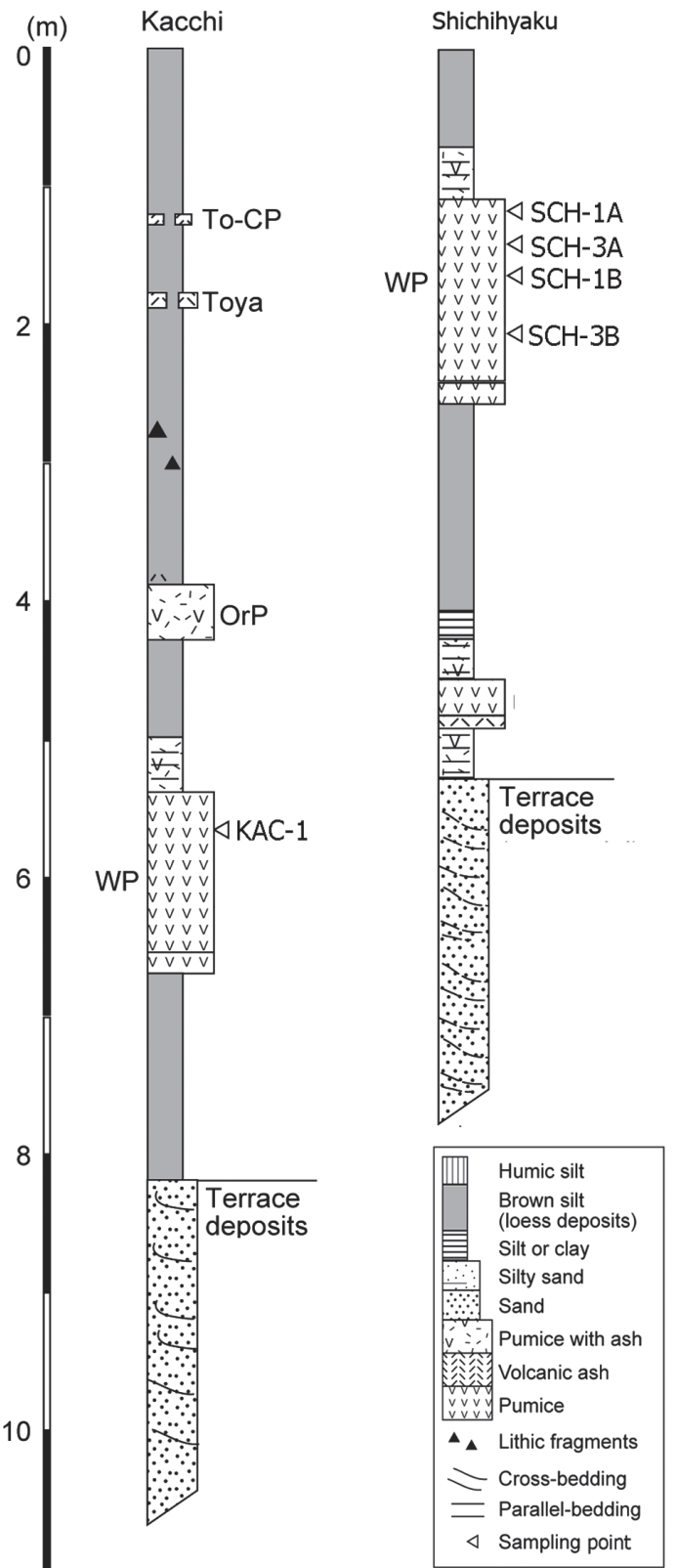

Fig. 2 Geological columns of two sampling areas shown in Fig. 1

Columns are from Matsu'ura et al. (2014). Abbreviation of tephra ; To-CP : Towada-Castera, Toya : Toya, OrP : Orange Pumice, WP : White Pumice. Only TL dating samples are shown in this figure. Sample points only for chemical analyses are referred in Fig. 3.
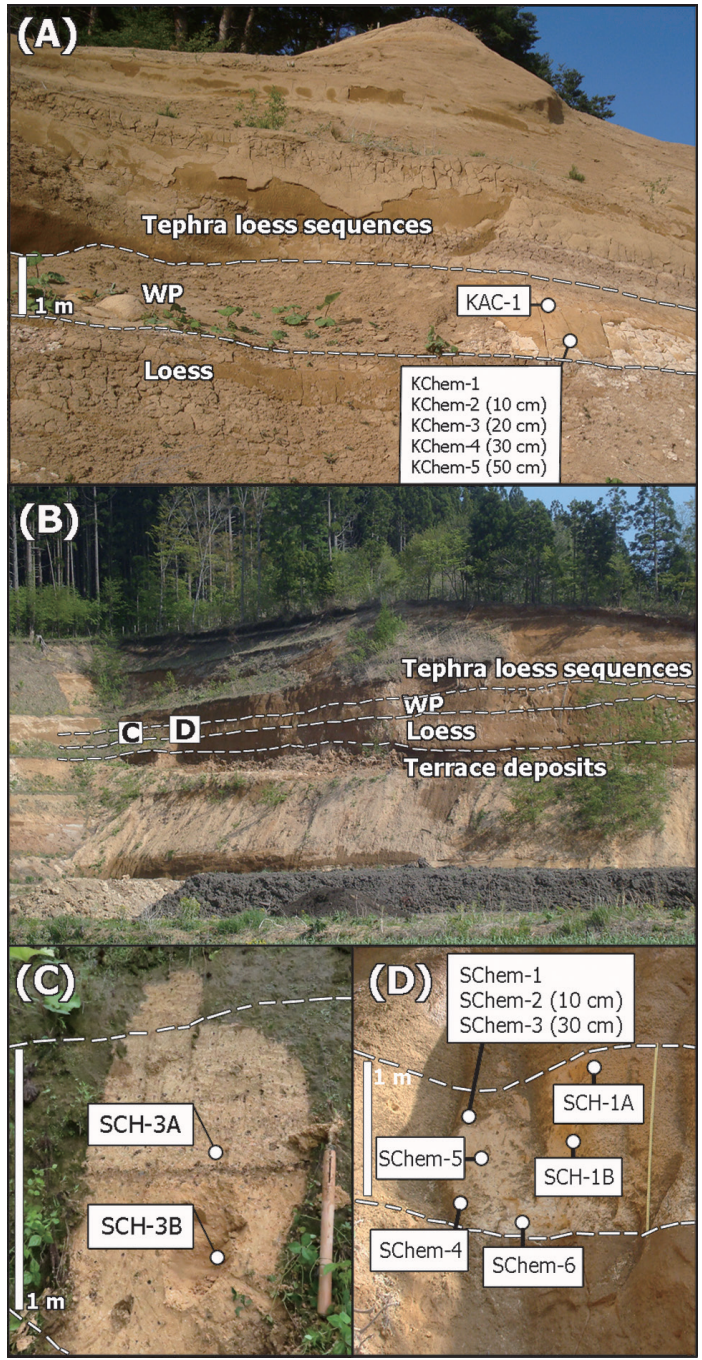

Fig. 3 Photographs showing WP on outcrops and sample positions

(A) Kacchi outcrop, (B) Shichihyaku outcrop, (C) and (D) Close up of WP. White dotted line indicates boundary of WP and other units.

\section{Sample preparation and analytical procedures}

The five samples for TL dating were dried at $60^{\circ} \mathrm{C}$ in the oven. Then the samples were wetsieved with running water, and dried to obtain fractions with diameters ranging between 63 and $250 \mu \mathrm{m}$. Magnetic minerals were eliminated from the fractions by frantz isodynamic magnetic separator. The fractions were treated with $35 \%$ 
hydrochloric acid $(\mathrm{HCl})$ for 1 hour to desolve carbonate minerals, and subsequently etched with 24\% hydrofluoric acid (HF) for 30 minutes at the temperature of $50^{\circ} \mathrm{C}$ to remove feldspars and the outer rinds of quartz exposed to alpha radiation. The final treatment was performed with $35 \%$ hydrochloric acid for 1 hour at the same temperature to remove fluorides, which might be formed during the previous step. After drying in an incubator at $50^{\circ} \mathrm{C}$ for 24 hours, purified quartz grains was carefully covered with aluminum foil for preventing TL signal loss.

A multiple aliquot regenerative dose method was performed for determining the ED values in this study. The purified quartz grains were separated into two portions, one was used to obtain the natural TL signal (NTL) and the other was used for obtaining artificial TL (ATL) signals. The latter was heated at $320^{\circ} \mathrm{C}$ for 5 hours and subsequently irradiated with ${ }^{60} \mathrm{Co}$ gamma ray source for receiving doses of 150 , 425.5 and $810 \mathrm{~Gy}$ (maximum irradiation rate is $25 \mathrm{~Gy} / \mathrm{min}$.) at Koga Isotope Co. Ltd. The unstable TL signal which was generated during gamma irradiation was eliminated by annealing at $130^{\circ} \mathrm{C}$ for 24 hours. TL signals were recorded with hand made machine (Takashima and Okuno, 2013). Detector is multi-alkaline type photomultiplier tube (Hamamatu Photonics, H7828-01) with red color range $(550-600 \mathrm{~nm})$ filters (ESCO PRODUCTS, OG-550 and HOYA, HA15). Heating rate is $1^{\circ} \mathrm{C} / \mathrm{s}$ with temperature range from 30 to $400^{\circ} \mathrm{C}$, and sample chamber was filled with nitrogen gas. The $\mathrm{ED}$ values were determined by counting the $330^{\circ} \mathrm{C}$ peak heights and calibrated against a growth curve drown from the ATL.

The $\mathrm{AD}$ values of the samples were evaluated from their $\mathrm{U}$, Th and $\mathrm{K}_{2} \mathrm{O}$ contents through gamma ray spectrometry. The measurements were performed for $290 \mathrm{~g}$ of samples with a $\mathrm{NaI}$ detector system using calibration by three standard nuclides and background samples. Errors of our samples were estimated as 3-5\% based on the previous work (Takashima et al., 2006 : Fig. 2). Using the dose-rate conversion factors proposed by Adamiec and Aitken (1998), beta and gamma rays contributions are calculated. In this calculation, quartz grain size is expected to be $0.2 \mathrm{~mm}$ for beta ray correction (Mejdahl, 1979) and cosmic-ray contributions are set to be $0.1 \mathrm{mGy} / \mathrm{a}$ as rough estimation based on the calculation in Takashima et al. (2006).

\section{Experimental Results and Discussion}

All samples show very clear red color TL glow with the peak at $330^{\circ} \mathrm{C}$. Fig. 4 (A) shows example of glow curve patterns of $\mathrm{KAC}-1$, and ED is calculated by the matching point of NTL to growth curve formed by ATL peak heights (Fig. 4 (B)). Table 1 shows TL ages of five WP samples obtained from Kacchi and Shichihyaku areas. TL age* means age calculated with annual dose which considers contribution from water, while TL age** assumes no water contents. The $\mathrm{AD}$ is calculated from the contents of $\mathrm{U}$, Th and $\mathrm{K}_{2} \mathrm{O}$ with two different water conditions as described in the previous chapter. Actual water contents of five samples from Kacchi and Sichihyaku are range from 75 to $168 \%$ (Water/ Solid).

Obtained TL ages are ranging form 343 to $624 \mathrm{ka}$ (in consideration of water contents) and 165 to $265 \mathrm{ka}$ (non water content assumed). Theoretically, true TL age will be between both data. We think TL age under no water condition is reliable because water content is expecting nearly zero considering whole geological time. At both of the sampling sites, WP has been above the water table and kept in a condition of low water content since its deposition. We collected samples from outcrop when water flow was very intense resulting in high water contents but duration of such condition would be very short in the geological time scale. This idea is not completely proved but the TL ages are almost concordant to expected ones when water contents are assumed to be zero for AD calculation at Shikotsu, Hokkaido and Unzen, Nagasaki (Takashima, 1995).

Based on the idea of no water contribution in AD calculation, TL ages of SCH-1A, SCH-1B and $\mathrm{SCH}-3 \mathrm{~A}$ are $187 \pm 29 \mathrm{ka}, 230 \pm 23 \mathrm{ka}$ and 229 $\pm 38 \mathrm{ka}$ (the weighted mean is $216 \pm 15 \mathrm{ka}$ ), which are concordant with a reported marine isotope age of WP, 205-210 ka (Matu'ura et al., in press). However, TL ages of SCH-3B and KAC-1, 165 $\pm 28 \mathrm{ka}$ and $265 \pm 33 \mathrm{ka}$ are inconsistent with the expected age. Among many age data for WP 

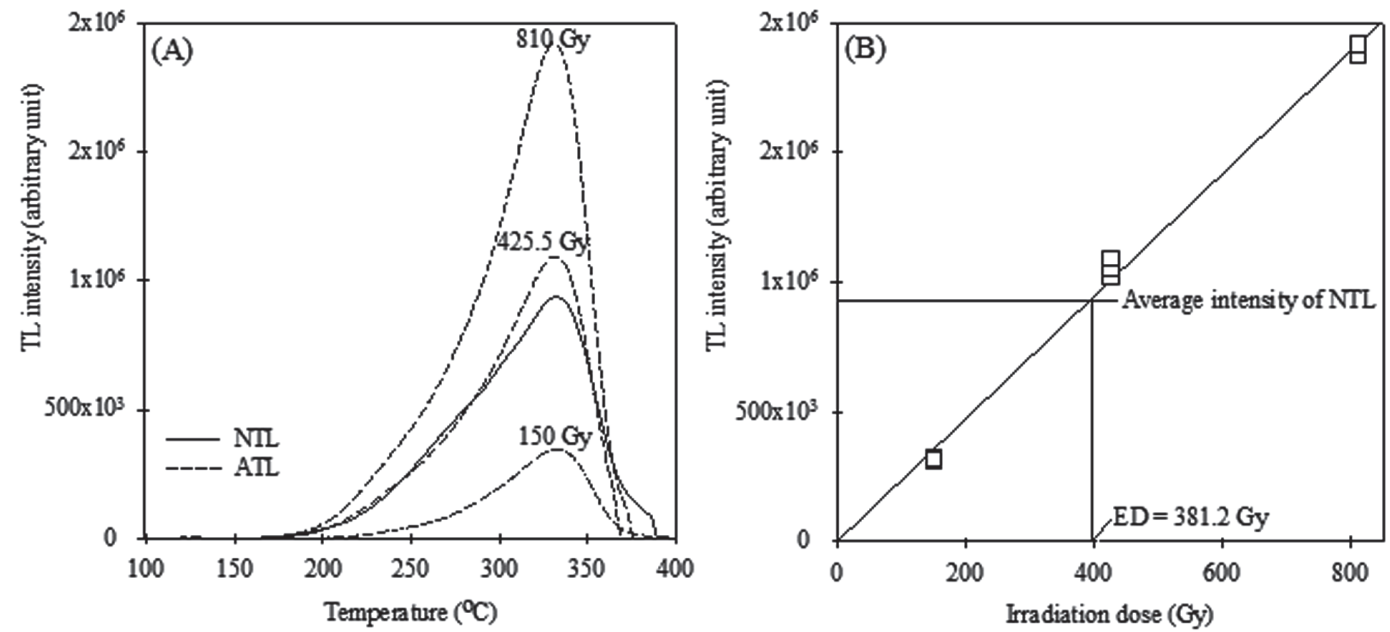

Fig. 4 TL glow curves (A) and growth curve (B) for KAC-1 sample

Table 1 TL dating results for White Pumice tephra (WP)

\begin{tabular}{lccccccccc}
\hline Sample & $\begin{array}{c}\mathrm{K}_{2} \mathrm{O} \\
(\%)\end{array}$ & $\begin{array}{c}\mathrm{U} \\
(\mathrm{ppm})\end{array}$ & $\begin{array}{c}\text { Th } \\
(\mathrm{ppm})\end{array}$ & $\begin{array}{c}\text { Water } \\
(\%)\end{array}$ & $\begin{array}{c}A D^{*} \\
(\mathrm{mGy} / \mathrm{a})\end{array}$ & $\begin{array}{c}\text { AD** } \\
(\mathrm{mGy} / \mathrm{a})\end{array}$ & $\begin{array}{c}\mathrm{ED} \\
(\mathrm{Gy})\end{array}$ & $\begin{array}{c}\text { TL age* } \\
(\mathrm{ka})\end{array}$ & $\begin{array}{c}\text { TL age** } \\
(\mathrm{ka})\end{array}$ \\
\hline $\mathrm{SCH}-1 \mathrm{~A}$ & $1.31 \pm 0.03$ & $1.64 \pm 0.04$ & $2.98 \pm 0.15$ & 163 & $0.653 \pm 0.042$ & $1.74 \pm 0.20$ & $325 \pm 34$ & $498 \pm 62$ & $187 \pm 29$ \\
$\mathrm{SCH}-1 \mathrm{~B}$ & $1.18 \pm 0.02$ & $2.09 \pm 0.05$ & $2.72 \pm 0.14$ & 168 & $0.635 \pm 0.037$ & $1.72 \pm 0.10$ & $396 \pm 32$ & $624 \pm 63$ & $230 \pm 23$ \\
$\mathrm{SCH}-3 \mathrm{~A}$ & $1.02 \pm 0.02$ & $1.86 \pm 0.05$ & $2.61 \pm 0.13$ & 75 & $0.848 \pm 0.053$ & $1.53 \pm 0.10$ & $351 \pm 54$ & $414 \pm 68$ & $229 \pm 38$ \\
$\mathrm{SCH}-3 \mathrm{~B}$ & $0.80 \pm 0.02$ & $1.68 \pm 0.05$ & $3.70 \pm 0.14$ & 104 & $0.671 \pm 0.038$ & $1.39 \pm 0.08$ & $230 \pm 36$ & $343 \pm 57$ & $165 \pm 28$ \\
$\mathrm{KAC}-1$ & $0.93 \pm 0.02$ & $1.64 \pm 0.04$ & $3.13 \pm 0.13$ & 107 & $0.687 \pm 0.038$ & $1.44 \pm 0.08$ & $381 \pm 42$ & $555 \pm 68$ & $265 \pm 33$ \\
\hline
\end{tabular}

$A D^{*}$ : Annual dose caluculated with consideration of water content,

$\mathrm{AD}^{* *}$ : Annual dose assuming no water content, ED: Equivalent dose,

TL age*: TL age caluculated with $A D^{*}$, TL age**: TL age caluculated with $\mathrm{AD}^{* * *}$.

(Miyauchi, 1985 ; Kudo et al., 2004 ; Kuwabara, 2007 ; Kudo and Kobayashi, 2013) to compare, this marine isotope age is the most reliable because it was integrated from the almost established biostratigraphic age data and isotope circle.

We collected many samples for check of chemical leaching. Fig. 5 is the plot of $U$ and Th versus $\mathrm{K}_{2} \mathrm{O}$ contents of samples from Kacchi (six samples) and Shichihyaku (10 samples) outcrops. Chemical data of Kacchi and Shichihyaku are plotted in different position even though they belong to the same fall tephra. Most of samples are plotted in a limited area for both locations. The TL ages of three samples $(\mathrm{SCH}-1 \mathrm{~A}, \mathrm{SCH}-1 \mathrm{~B}$ and $\mathrm{SCH}-3 \mathrm{~A})$ close to expecting age (205-210 ka) are all plotted in that concentrated zone. On the other hand, other two samples $(\mathrm{SCH}-3 \mathrm{~B}$ and $\mathrm{KAC}-1)$ are plotted outside of concentrated zone of each area. The $\mathrm{SCH}-3 \mathrm{~B}$ is plotted in lower $\mathrm{K}_{2} \mathrm{O}$ side (Fig. $5^{-} \mathrm{A}$ and $5-\mathrm{B}$ ), and $\mathrm{KAC}^{-1}$ data is plotted lower Th side (Fig. $5-\mathrm{B}$ ). It is difficult to explain how the chemical leaching and other factors contributed the TL accumulation, chemical leaching and other factors. Simple explanation is chemical leaching for $\mathrm{KAC}-1$, which cause low AD (resulting in older TL age) and setting in wet position for $\mathrm{SCH}-3 \mathrm{~B}$, which cause low TL accumulation condition (resulting in younger TL age). Another one sample from Shichihyaku (SChem-4, not identified sample no. on Fig. 5) is plotted outside of concentrated zone. It is highly possible to give the unreliable TL age although we did not performed full TL measurement.

Chemical anomaly is difficult to identify even by careful field observation. Samples for TL age determination must be chosen after examining 

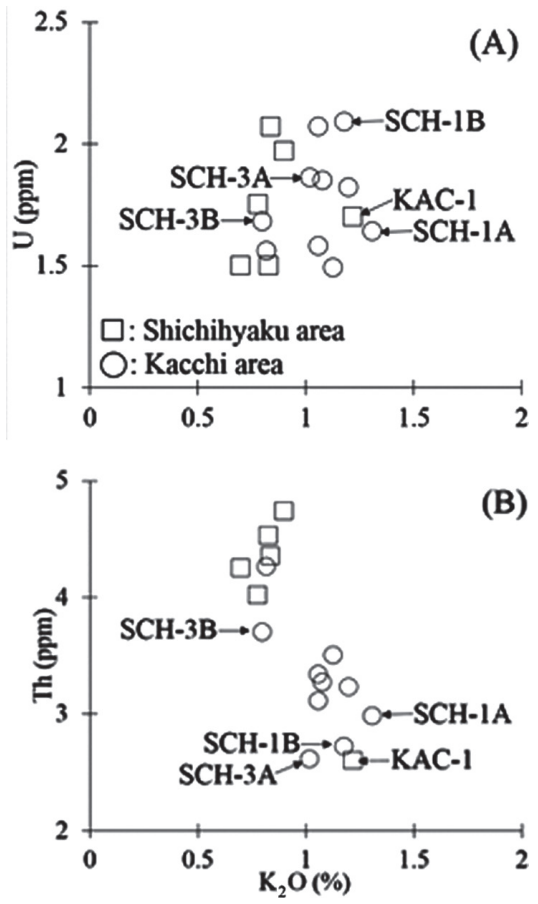

Fig. 5 Plot of chemical data of whole samples from two areas

chemistry of samples as is shown in Fig. 5. Unconsolidated tephra is important materials and easy to find samples for TL age determination. Careful sample selection based on chemical screening is essential together with examination of sample characteristics (e.g., origin, accidental materials, thickness, geologic history). Though we collect samples carefully from outcrops and/ or cores but they only show condition of present time. There are some possibilities of complex thermal history, alteration, reworks, etc. Accordingly, it is stressed that the careful sample selection must be essential for establishment of unconsolidated tephra TL chronology.

\section{Conclusions}

We measured TL age of White Pumice tephra (WP) as an example of unconsolidated tephra which underwent chemical leaching and water content change. WP is an important age indicator for Middle Pleistocene marine terrace chronology at the Kamikita plain, Aomori Prefecture and its age has been correlated to mid MIS 7, 205-210 $\mathrm{ka}$ in deep-sea sediments. Important point is collecting many samples from a tephra layer and preliminary chemical analyses to select suitable samples for TL measurement. The main conclusions obtained are as follows.

(1) The three TL ages form the selected samples with averaging chemical contents are $187 \pm$ $29 \mathrm{ka}, 230 \pm 23 \mathrm{ka}$ and $229 \pm 38 \mathrm{ka}$ (weighted mean of $216 \pm 15 \mathrm{ka}$ ), which shows very close to a reported age of WP (MIS 7b ; 205-210 ka), correlated with $\delta^{18} \mathrm{O}$ stratigraphy of deep-sea sediments.

(2) The TL ages of two samples with chemically abnormal localities shows over or underestimated ages. It is difficult to find the reason for these unreliable ages. Possible reason are chemical leaching (shows older TL age) and staying at wet condition (shows younger TL age).

(3) The process of many sample collection at same outcrop and selection for chemically stable one are recommended way to obtain accurate TL age measurement for unconsolidated tephra.

(4) Water content of sampled WP is very high but TL age assuming no water condition is reliable because water content is expecting nearly zero through the whole geological time.

\section{Acknowledgements}

We express our sincere thanks to Dr. Hinako Sato, Akita University, for her help to chemical treatment of sample processing.

\section{References}

Adamiec, G. and Aitken, M. (1998) Dose rate conversion factors : update. Ancient TL, 16, 37-50.

Ganzawa, Y. and Maeda, M. (2009) $390-410^{\circ} \mathrm{C}$ isothermal red thermoluminescence (IRTL) dating of volcanic quartz using the SAR method. Radiation Measurement, 44, 517-522.

Hashimoto, T., Nakagawa, T., Hong, D.G. and Takano, M. (2002) An automated system for both red/blue thermoluminescence and optically stimulated luminescence measurement. Journal of Nuclear Science and Technology, 39, 108-109.

Ichikawa, Y., Hagihara, N. and Nagatomo, T. (1982) Dating of pyroclastic flow deposits by means of the quartz inclusion method. PACT, 6, 409-416.

Koike, K. and Machida, H. (2001) Atlas of Quaternary Marine terraces in the Japanese Island. $105 \mathrm{p}$, University of Tokyo Press. $(\mathrm{J}+\mathrm{E})$ 
Kudo, T. and Kobayashi, M. (2013) Radiometric dating of tephras from pre-caldera and caldera forming stage, Towada volcano, Northeast Japan. Bulletin of Geological Survey of Japan, 64, 305-311. (J+E)

Kudo, T., Takarada, S. and Sasaki, M. (2004) Geology and volcanic history of Kita-Hakkoda volcanic group, northeast Japan. Journal of Geological Society of Japan, 110, 271-289. (J+E)

Kuwabara, T. (2007) Fission-track dating of the Middle Pleistocene Shirobeta tephra (WP) in the Kamikita plain, northeast Japan. Quaternary Research (Daiyonki-kenkyu), 46, 433-436. (J+E).

Machida, H. and Arai, F. (2003) Atlas of tephra in and around Japan. Revised Edition, 336 p, University of Tokyo Press. $(\mathrm{J}+\mathrm{E})$

Matsu'ura, T., Furusawa, A., Shimogama, K., Goto, N. and Komatsubara, J. (2014) Late Quaternary tephrostratigraphy and cryptotephrostratigraphy of deep-sea sequences (Chikyu C9001C cores) as tools for marine terrace chronology in NE Japan. Quaternary Geochronology, 23, 63-79.

Matsu'ura, T., Kimura, J., Chang, Q. and Komatsubara, J. (in press) Using tephrostratigraphy and cryptotephrostratigraphy to re-evaluate and improve the Middle Pleistocene age model for marine sequences in northeast Japan (Chikyu C9001C). Quaternary Geochronology, http://dx.doi.org/10.1016/ j.quageo. 2016.11.001.

Mejdahl, V. (1979) Thrermoluminecence dating: Betadose attenuation in quartz grains. Archaeometry, 21, 61-72.

Miyauchi, T. (1985) Quaternary crustal movements estimated from deformed terraces and geologic structures of the Kamikita coastal plain, northeast Japan. Geographical Review of Japan, 58, 492-515. $(\mathrm{J}+\mathrm{E})$

Miyauchi, T. (1987) Quaternary tectonic movements of the Kamikita coastal plain, northeast Japan. Geo- graphical Review of Japan, 60, 1-19.

Nagatomo, T., Shitaoka, Y. and Nishimura, S. (2005) Comparison of Results between TL and OSL dating of the same tephras. Bulletin of Nara University of Education, 54, 1-10. (J+E)

Ogawa, A., Kurita, H. and Ganzawa, Y. (2011) ASRRTL and IRTL dating of volcanic single quartz grain extracted from Towada-Hachinohe (To-H) pyroclastic flow. Quaternary Research (Daiyonkikenkyu), 50, 170-180. (J+E)

Shitaoka, Y., Takemura, K. and Nagatomo, T. (2013) Thermoluminescence dating of marker tephras during the past 100,000 years in Japan. Quaternary Research (Daiyonki-kenkyu), 52, 139-150. (J+E)

Takashima, I. (1995) Thermoluminescence dating: With special reference to accuracy and reliability of age determination using quartz of volcanic rocks. Quaternary Research (Daiyonki-kenkyu), 34, 209220. $(\mathrm{J}+\mathrm{E})$

Takashima, I. and Okuno, M. (2013) Thermoluminescence (TL) dating technique applied for volcanic rocks : Establishment of reliability by sample selection and measuring method. Monthly Earth, Special Issue, no. 62, 26-31. (J)

Takashima, I., Murakami, H., Hong, G.H., Eddy Sucipta, I.G.B., Mouri, Y. and Shibata, Y. (2006) Thermoluminescence dating of Pleistocene volcanic rocks and pumice flow deposits in Onikobe and adjacent areas, NE Japan. Japanese Magazine of Mineralogical and Petrological Sciences, 35, 70-77. (J+E)

Tsukamoto, S. and Iwata, S. (2005) Recent development in luminescence dating : On the extending the age range and behavior of different OSL components from quartz. Journal of Geological Society of Japan, 111, 643-653. (J+E)

(J) in Japanese, $(\mathrm{J}+\mathrm{E})$ in Japanese with English Abstract. 


\section{化学分析で選別した試料を用いた上北平野の White Pumice テフラ（WP）の熱ルミネッセンス年代}

チューンピー ティラポン*1, a $・$ 松浦旅人*2 ・西川 治*3 $・$ 内田 隆*3 $・$ 高島 勲*4

\section{[要旨 $]$}

青森県上北平野に分布する海成段丘上の中期更新世の 未固結 White Pumice テフラ(WP) について, Multiple aliquot regeneration 法による熱ルミネッセンス年代を 求めた。試料は, 㤎地及び艺苩の露頭から各 6 及び 10 個を採取し，溶脱による化学組成変化を評価した．これ ら 16 試料について, U, Th, K という放射性核種を測定 した. TL 年代測定は, 5 試料について実施した. これら のうち 3 試料は $187 \pm 29 \mathrm{ka}, 230 \pm 23 \mathrm{ka}, 229 \pm 38 \mathrm{ka}$ (加 重平均: $216 \pm 15 \mathrm{ka}$ ) であり, 深海底堆積物コアの海洋
酸素同位体比層序から求められた WP の年代 (MIS 7b ; 205-210 ka) とほぼ一致した。残りの 2 試料の年代は $165 \pm 28 \mathrm{ka}$ 及び $265 \pm 33 \mathrm{ka}$ であり, 既知年代とは一致 しない. 前 3 試料はすべての分析デー夕をプロットした $\mathrm{U}-\mathrm{K}_{2} \mathrm{O}, \mathrm{Th}-\mathrm{K}_{2} \mathrm{O}$ ダイアグラム上の集中域にあるのに対 し, 後者の 2 試料は集中域から離れた值を持っている. 未固結試料であるテフラの TL 年代測定では, 化学分析 による選別で適正な年間線量を持ったものが測定対象と なると予想される.

キーワード : White Pumice テフラ (WP), TL 年代測定, 未固結試料, 化学成分溶脱, 上北平野, 東北日本

\footnotetext{
*1 秋田大学大学院工学資源学研究科 =010-8502 秋田市手形学園町 1-1.

*2 東京都港区.

*3 秋田大学大学院国際資源学研究科 T010-8502 秋田市手形学園町 1-1.

*4 秋田大学名誉教授 $\overline{\mathbf{T}} 010-0851$ 秋田市手形蛇野.

*a Corresponding author : chuenpee_t@yahoo.com
} 